\title{
KONSEP EKONOMI PADA MASA RASULULLAH NABI MUHAMMAD SAW
}

\section{Musdalifah ( 90100118006)}

Kegiatan manusia di bumi dalam memenuhi kebutuhan-kebutuhannya pada jaman dulu cenderung mengalami proses yang sama, bagaimana cara berburu, meramu dan bercocok tanam. Demikian juga perilaku manusia saat ini, mengalami kecenderungan ke arah yang sama, bagaimana mendapatkan pekerjaan, mempertahankan dan menyelesaikannya. Hal ini menandakan bahwa manusia memiliki pola perilaku untuk memenuhi kebutuhan yang relative sama walaupun tidak persis. Proses ini yang berulang dari pemenuhan kebutuhan ini menjadikan manusia dapat mengidentifikasi, mengklasifikasi dan memverifikasi pola perilaku yang lebih efektif dalam memenuhi kebutuhan hidupnya.(Efyanti \& Ekonomi, 2015).

Secara umum, ekonomi adalah perilaku manusia yang berhubungan dengan bagaimana proses dan cara memperoleh dan mendayagunakan produksi, distribusi, dan konsumsi. Ekonomi berkaitan dengan perilaku manusia yang didasarkan pada landasan serta prinsip-prinsip yang menjadi dasar acuan. Ilmu ekonomi Islam sebagai sebuah studi ilmu pengetahuan modern baru yang muncul pada tahun 1970-an, akan tetapi pemikiran tentang ekonomi Islam telah muncul sejak Islam itu diturunkan melalui Nabi Muhammad SAW. (Ibnuddin, 2019)

Pada masa pra Islam, hakam atau juru damai itu harus memenuhi beberapa kualifikasi. Di antara syarat yang terpenting bagi mereka adalah harus cakap dan memiliki kekuatan supranatural atau adikodrati. Oleh karena itu, dalam pemeriksaan dan penyelesaian persengketaan di kalangan mereka, hakam lebih banyak menggunakan kekuatan firasat daripada menghadirkan alat-alat bukti seperti saksi-saksi atau pengakuan. Namun setelah Islam datang dan berkembang yang dibawakan oleh Nabi Muhammad Saw, lembaga perwasitan terus berjalan dan dikembangkan sebagai alternatif penyelesaian sengketa dengan memodifikasi yang pernah berlaku pada masa praIslam.(Rangkuti, 2011)

Adapun perjalanan hidup Nabi Muhammad SAW yang Mempelajari sekaligus mengkaji keilmuan yang luar biasa, serta kaya dalam mencerahkan sesuatu. Oleh karena itu Manusia merupakan tauladan Nabi Muhammad yang mencakup segala aspek kehidupan sehingga tak habis-habisnya untuk dikaji secara terus menerus. Belum mampunya umat islam mengambil suri tauladan Nabi Muhammad SAW secara holistic dan komprehensif dikarenakan kurangnya 
kesadaran dalam mengkaji islam, dan ketidakmampuan melihat perjalanan hidup Rasulullah SAW secara lengkap dan holistic baik dari dimensi social, politik , militer, edukasi, dan legal yang kemudian menformulasikan nilai-nilai ketauladanan tersebut kedalam suatu model yang dapat di teladani dengan mudah. Salah satu kriteria kesuksesan seseorang adalah keberhasilan dalam memimpin keluarga. Nabi Muhammad SAW adalah suri tauladan yang baik dalam kepemimpinan keluarga. Meskipun banyak kritikan yang di berikan kepada beliau oleh kalangan non-muslim, berkaitan dengan rumah tangga beliau, Nabi Muhammad SAW sosok yang baik dalam kepemimpinannya.(Umam, 2018).

Sistem Islam memberi perhatian terhadap kesempurnaan mekanisme pasar. Mekanisme pasar yang sempurna adalah resultan dari kekuatan yang bersifat massal dan impersonal, yaitu merupakan fenomena alamiah.8 Pasar yang bersaing sempurna dapat menghasilkan harga yang adil bagi penjual atau pembeli. Karena jika mekanisme pasar terganggu maka harga yang adil tidak akan tercapai. Harga yang adil akan mendorong para pelaku pasar untuk bersaing dengan sempurna. Sistem Islam sangat mendorong konsep harga yang adil, terbuka dan sesuai mekanisme pasar yang sempurna. Konsep makanisme pasar dalam Islam dapat dirujuk kepada hadisRasululllah saw sebagaimana disampaikan oleh Anas RA, sehubungan dengan adanya kenaikan harga-harga barang di kota Madinah. ( et al., 2018)

Efyanti, Y., \& Ekonomi, I. D. (2015). JYasni Efyanti, Islam Dan Ekonomi[. 15, 15-30.

Ibnuddin. (2019). Pemikiran Ekonomi Islam Pada Masa Nabi Muhammad. Risalah, Vol.5, No.(1), 51-61. https://doi.org/10.5281/zenodo.3551174

Rangkuti, R. Y. (2011). Sistem Penyelesaian Sengketa Ekonomi Islam: Instrumen Penting bagi Konsep Ekonomi Islam Mendatang. Asy-Syir'ah: Jurnal Ilmu Syari'ah Dan Hukum, Vol 45(2). http://asy-syirah.uin-suka.com/index.php/AS

Umam, M. K. (2018). Imam Para Nabi : Menelusur Jejak Kepemimpinan Dan. 60 Jurnal AlHikmah, 6 no., 59-74.

Parakkasi, I., \& Kamiruddin, K. (2018). Analisis Harga Dan Mekanisme Pasar Dalam Perspektif Islam. LAA MAISYIR : Jurnal Ekonomi Islam, 5(1), 107-120. https://doi.org/10.24252/laamaisyir.v5i1a5 
